\title{
Co-Hydrolysis of Lignocellulosic Biomass for Microbial Lipid Accumulation
}

\author{
Zhenhua Ruan, ${ }^{1}$ Michael Zanotti, ${ }^{1}$ Yuan Zhong, ${ }^{1}$ Wei Liao, ${ }^{1}$ Chad Ducey, ${ }^{2}$ Yan Liu ${ }^{1}$ \\ ${ }^{l}$ Department of Biosystems and Agricultural Engineering, Michigan State University, \\ East Lansing, Michigan 48824; telephone: +1-517-432-7387; fax: +1-517-432-2892; \\ e-mail: liuyan6@msu.edu \\ ${ }^{2}$ Werks Management, LLC, Fishers, Indiana
}

\begin{abstract}
The herbaceous perennial energy crops miscanthus, giant reed, and switchgrass, along with the annual crop residue corn stover, were evaluated for their bioconversion potential. A co-hydrolysis process, which applied dilute acid pretreatment, directly followed by enzymatic saccharification without detoxification and liquid-solid separation between these two steps was implemented to convert lignocellulose into monomeric sugars (glucose and xylose). A factorial experiment in a randomized block design was employed to optimize the co-hydrolysis process. Under the optimal reaction conditions, corn stover exhibited the greatest total sugar yield (glucose + xylose) at $0.545 \mathrm{gg}^{-1}$ dry biomass at $83.3 \%$ of the theoretical yield, followed by switch grass $\left(0.44 \mathrm{~g} \mathrm{~g}^{-1}\right.$ dry biomass, $65.8 \%$ of theoretical yield), giant reed $\left(0.355 \mathrm{~g} \mathrm{~g}^{-1}\right.$ dry biomass, $64.7 \%$ of theoretical yield), and miscanthus $\left(0.349 \mathrm{~g} \mathrm{~g}^{-1}\right.$ dry biomass, $58.1 \%$ of theoretical yield). The influence of combined severity factor on the susceptibility of pretreated substrates to enzymatic hydrolysis was clearly discernible, showing that co-hydrolysis is a technically feasible approach to release sugars from lignocellulosic biomass. The oleaginous fungus Mortierella isabellina was selected and applied to the co-hydrolysate mediums to accumulate fungal lipids due to its capability of utilizing both $\mathrm{C} 5$ and $\mathrm{C} 6$ sugars. Fungal cultivations grown on the co-hydrolysates exhibited comparable cell mass and lipid production to the synthetic medium with pure glucose and xylose. These results elucidated that combining fungal fermentation and co-hydrolysis to accumulate lipids could have the potential to enhance the utilization efficiency of lignocellulosic biomass for advanced biofuels production.

Biotechnol. Bioeng. 2013;110: 1039-1049.
\end{abstract}

(c) 2012 Wiley Periodicals, Inc.

KEYWORDS: co-hydrolysis; lignocellulosic biomass; oleaginous fungus; lipid accumulation

Correspondence to: Y. Liu

Received 15 August 2012; Revision received 16 October 2012;

Accepted 22 October 2012

Accepted manuscript online 1 November 2012;

Article first published online 26 November 2012 in Wiley Online Library

(http://onlinelibrary.wiley.com/doi/10.1002/bit.24773/abstract)

DOI 10.1002/bit.24773

\section{Introduction}

Lignocellulosic biomass represents the most abundant natural polymer in the biosphere, and interest in its use as a feedstock for the production of advanced biofuels has gained momentum in recent years as shown by various government directives. The Renewable Fuels Standard 2 provision in the United States Energy Independence and Security Act of 2007 mandates the production of 36 billion gallons of biofuels by 2022, with 16 billion gallons coming from lignocellulosic sources while capping conventional biofuels (i.e., corn starch-based ethanol) at 15 billion gallons (Coyle, 2010). Support for lignocellulosic fuels is owed not only to its large supply, but also its ability to mitigate greenhouse gas emissions, avoid competition with food resources, stimulate rural economies, and provide a stable and secure source of energy production (Coyle, 2010). Many sources of lignocellulosic biomass exist, including municipal solid wastes, pulp and paper wastes, forest and agricultural residues, and dedicated woody and herbaceous perennial energy crops. Herbaceous perennial energy crops in particular, have been the focus of much attention due to their positive environmental characteristics. Compared to annual crops, perennials, once established, do not need reseeding, and require lower inputs (i.e., water, fertilizer, pesticide, tillage). Additionally they can often be grown on uncultivated or marginal lands where their deep root systems act to reduce soil erosion, increase soil fertility, and accumulate greater soil organic carbon than their annual counterparts (i.e., corn or canola) (Williams et al., 2009). Among the twenty perennial grasses studied by the European Union, the most promising in terms of biofuel production were: miscanthus, giant reed, switchgrass, and reed canarygrass (Lewandowski et al., 2003). The first three crops, along with corn stover will be the primary focus of this investigation.

Many studies have been devoted to the pretreatment and enzymatic hydrolysis of the herbaceous perennial energy crop switchgrass, however, information about the recalcitrance and bioconversion potential of miscanthus and giant 
reed is still limited. Wet explosion (Sorensen et al., 2008), ammonia fiber expansion (Murnen et al., 2007), one-step extrusion/ $\mathrm{NaOH}$ (de Vrije et al., 2002), and aqueousethanol organosolvent treatments were applied for the bioconversion of miscanthus to fermentable sugars (Brosse et al., 2010). Dilute acid pretreatment (Anderson et al., 2008; Dien et al., 2006; Scordia et al., 2011; Shatalov and Pereira, 2012) and ethanol-alkaline treatment (Shatalov and Pereira, 2005) were carried out for giant reed bioconversion. All of the aforementioned studies employed traditional methods of biomass processing where, after pretreatment, the solids are separated from the liquid stream, washed to neutralize and detoxify the remaining solids, then subjected to enzymatic hydrolysis in order to extract glucose monomers (Decker et al., 2009). Depending on the particular pretreatment method, the discarded liquid stream will often contain a large percentage of the solubilized xylose, and to a lesser extent, glucose monomers, and soluble lignin. Since xylose represents a significant fraction of the lignocellulosic biomass, it is critical from an engineering and economic standpoint to retain this fraction in order to improve pretreatment efficiency. Additionally, such a process requires large amounts of water to adjust the $\mathrm{pH}$ and detoxify the solid biomass, and separation of the solid and liquid streams is timely and introduces the possibility of contamination (Studer et al., 2011). Therefore, development of a novel process (co-hydrolysis), which eliminates liquidsolid separation, detoxification or washing of the pretreated solids, and directly carries out enzymatic hydrolysis after pretreatment would make a significant contribution to the production of advanced biofuels. To date, comprehensive evaluations of co-hydrolysis of lignocellulosic biomass are sparse. A few researchers have studied the effects of higher solids loading for un-detoxified pretreated wheat straw (Georgieva et al., 2008; Jorgensen et al., 2007), the effects of increasing enzyme dosage in comparing washed-solids of wheat straw versus whole-slurry hydrolysis (Felby et al., 2003), and the combined effects of severity, and enzyme and solid loadings on co-hydrolysis performance of populus (Studer et al., 2011).

Realizing the potential benefits of co-hydrolysis comes with its own challenges, such as utilizing microbes that are robust enough to withstand elevated levels of toxins specific to each biomass and pretreatment method, while containing the ability to ferment both hexose and pentose sugars into biofuels. There are few studies on the bioconversion of both the hexose and pentose fractions of herbaceous perennial energy crops like switchgrass, miscanthus, and giant reed. The extreme thermophilic bacterium Thermotoga elfii metabolized undetoxified miscanthus hydrolysate containing glucose and xylose for hydrogen production, while the yeast Scheffersomyces stipitis CBS6054 was able to convert giant reed hydrolysate to ethanol (Scordia et al., 2012). Our previous study found that the oleaginous mold Mortierella isabellina, when grown on corn stover co-hydrolysate, could produce lipid yields comparable to those from synthetic hydrolysate without toxins (Ruan et al., 2012). In addition, there is still limited information regarding its lipid production from herbaceous perennial energy crops, even though lipid accumulation by $M$. isabellina from lignocellulosic biomass has been studied (Economou et al., 2011; Xing et al., 2012). Thus, the aim of this study is to provide a comparative evaluation of $M$. isabellina lipid accumulation on the co-hydrolysates of four different lignocellulosic feedstocks: switchgrass, giant reed, miscanthus, and corn stover, using a co-hydrolysis process for bioconversion.

\section{Materials and Methods}

\section{Lignocellulosic Biomass}

Corn stover and switchgrass were collected from the Michigan State University Crop and Soil Science Teaching and Research Field Facility. Miscanthus and giant reed were obtained from Werks Management, LLC (Fishers, IN). Each feedstock was air-dried and ground using a mill (Willey Mill, Standard Model No. 3; Arthur H. Thomas, Philadelphia, PA) with a $2 \mathrm{~mm}$ size screen; all materials were then sieved to make a particle size distribution of $<30$ mesh $(<1.6 \mathrm{~mm})$ but $>80$ mesh $(>1 \mathrm{~mm})$. The biomass samples were analyzed for cellulose, xylan, and lignin content according to the National Renewable Energy Laboratory's (NREL) analytical procedure for determination of structural carbohydrates and lignin in biomass (Sluiter and National Renewable Energy Laboratory (U.S.), 2008).

\section{Dilute Acid Pretreatment}

To evaluate the combined glucose and xylose recovery from cellulose and xylan in each biomass sample, dilute acid pretreatment was performed with a factorial randomized block design. Dilute acid concentration, pretreatment time, and temperature were the factors investigated. Eighteen treatments with two replicates were applied to each lignocellulosic biomass for a total of 36 individual samples per feedstock. Each sample was treated in a screw cap $125 \mathrm{~mL}$ serum bottle and placed in an autoclave (Brinkmann 2540M; Tuttnauer USA Co. Ltd., Hauppauge, NY). Dilute acid pretreatments were carried out at sulfuric acid concentrations of $1 \%, 2 \%$, and $3 \%(\mathrm{w} / \mathrm{w})$, respectively. Retention times of 1,2 , and $3 \mathrm{~h}$ were applied once the reaction temperature reached its predetermined level of 110,120 , or $130^{\circ} \mathrm{C}$, respectively. Biomass concentration for pretreatment was fixed at $10 \%$ dry matter. After dilute acid pretreatment, biomass slurries were titrated to a $\mathrm{pH}$ of $4.5-5$ with $5 \mathrm{~mol} \mathrm{~L}^{-1}$ sodium hydroxide.

\section{Enzymatic Saccharification}

After dilute acid pretreatment and $\mathrm{pH}$ adjustment of the biomass slurry, various amounts of $0.1 \mathrm{~mol} \mathrm{~L}^{-1}$ citrate buffer ( $\mathrm{pH} 4.8$ ) and an enzyme mixture consisting of $34.85 \mathrm{mg}$ 
cellulase (Accellerase $1500^{\circledR}$, protein content $69.7 \mathrm{mg} \mathrm{mL}^{-1}$, lot number 3016295230; Genencor, Palo Alto, CA) and $4.31 \mathrm{mg}$ xylanase (Accellrase XY, protein content $43.1 \mathrm{mg} \mathrm{mL}^{-1}$, lot number 4900667792; Genencor) per gram of initial dry biomass were added to the slurry to achieve a final dry matter concentration of $8 \%$ for all pretreated solutions. All of the resulting samples were incubated at $50^{\circ} \mathrm{C}$ in a shaking incubator at $150 \mathrm{rpm}$ for $72 \mathrm{~h}$. All enzymatic hydrolysis experiments were carried out in duplicates. After hydrolysis, the samples were removed from the shaker and put on ice to stop the reaction; the hydrolysate was separated by centrifugation at 7,025g for 5 min to obtain a clear sugar solution, which was then filtered through a $0.22 \mu \mathrm{m}$ polyethersulfone membrane filter for HPLC analysis. The clear enzymatic hydrolysate solutions were stored in a $4^{\circ} \mathrm{C}$ refrigerator for further use.

\section{Microorganisms and Culture Conditions}

M. isabellina ATCC 42613 was obtained from the American Type Culture Collection (Manassas, VA). This strain was first cultured on potato dextrose agar (Sigma-Aldrich, St. Louis, MO) to produce spores at $30^{\circ} \mathrm{C}$. After 14 days cultivation, the spores were washed with sterilized distilled water to obtain a spore suspension (stored at $4^{\circ} \mathrm{C}$ ). Seed cultures were grown with $24 \mathrm{~g} \mathrm{~L}^{-1}$ potato dextrose broth (Sigma-Aldrich) with $8 \mathrm{~g} \mathrm{~L}^{-1}$ yeast extract at $25^{\circ} \mathrm{C}$ and $180 \mathrm{rpm}$ for 2 days in a rotary shaker (Thermal Scientific, Odessa, TX) with a spore concentration of $1-2 \times 10^{7}$ spore $\mathrm{mL}^{-1}$. The salt medium of submerged batch cultures contained: $\mathrm{KH}_{2} \mathrm{PO}_{4}\left(1 \mathrm{~g} \mathrm{~L}^{-1}\right.$; Mallinckrodt Bakker, St. Thomas, US Virgin Islands), $\mathrm{MgCl}_{2} \cdot 6 \mathrm{H}_{2} \mathrm{O} \quad\left(0.5 \mathrm{~g} \mathrm{~L}^{-1}\right.$; Mallinckrodt Bakker), $\mathrm{ZnSO}_{4} \cdot 7 \mathrm{H}_{2} \mathrm{O}\left(0.0014 \mathrm{~g} \mathrm{~L}^{-1}\right.$; SigmaAldrich), $\quad \mathrm{MnSO}_{4} \cdot \mathrm{H}_{2} \mathrm{O}\left(0.0016 \mathrm{~g} \mathrm{~L}^{-1} ;\right.$ Sigma-Aldrich $)$, $\mathrm{CoCl}_{2} \cdot 6 \mathrm{H}_{2} \mathrm{O}\left(0.0036 \mathrm{~g} \mathrm{~L}^{-1}\right.$; Sigma-Aldrich), and $\mathrm{FeSO}_{4}$. $7 \mathrm{H}_{2} \mathrm{O} \quad\left(0.00275 \mathrm{~g} \mathrm{~L}^{-1}\right.$; Sigma-Aldrich). $2.74 \mathrm{~g} \mathrm{~L}^{-1}$ yeast extract (DOT Scientific Inc., Burton, MI) was used as the sole nitrogen source. The carbon sources were synthetic sugars (composed of a mixture of glucose and xylose using similar concentrations found in the co-hydrolystates), and lignocellulosic biomass co-hydrolysates. Corn stover and switchgrass co-hydrolysates were diluted to obtain similar sugar concentrations to those found in miscanthus and giant reed co-hydrolysates. The $\mathrm{pH}$ of the medium was adjusted to $6.0 \pm 0.1$ before autoclaving. Two hundred fifty milliliter Erlenmeyer flasks were filled with $50 \mathrm{~mL}$ of growth medium and sterilized at $121^{\circ} \mathrm{C}$ for $15 \mathrm{~min}$. The growth medium was inoculated with a $10 \%(\mathrm{v} / \mathrm{v})$ seed culture and cultivated at $25 \pm 0.5^{\circ} \mathrm{C}$ on a rotary shaker (Thermal Scientific) with an agitation speed of $180 \mathrm{rpm}$.

\section{Mass Balance}

Mass balance analysis was based on the co-hydrolysis and fermentation data. Lipid production was calculated by the amount of lipid accumulated during fermentation divided by the dry weight of initial lignocellulosic biomass.

\section{Analytical Methods}

The sugar yield from combined dilute acid pretreatment and enzymatic hydrolysis was calculated to evaluate the performance of co-hydrolysis and conduct the mass balance analysis. The sugar yield was determined by the ratio of the measured amount of sugars (glucose and xylose) in co-hydrolysates to the dry weight of initial biomass and also calculated as the percent of theoretical combined glucose and xylose yield.

The combined severity factor ( $\log \mathrm{CS}$ ), which couples reaction conditions of time, temperature, and acid concentration into a single variable, was used to compare sugar yields. Combined severity is calculated as follows: $\log \mathrm{CS}=t \exp \left[\left(T_{\mathrm{H}}-T_{\mathrm{R}}\right) / 14.75\right]-\mathrm{pH}$, where $t$ is reaction time in minutes, $T_{\mathrm{R}}$ is the hydrolysis temperature in ${ }^{\circ} \mathrm{C}$, and $T_{\mathrm{H}}$ is a reference temperature of $100^{\circ} \mathrm{C}$ (Lloyd and Wyman, 2005); after pretreatment, the $\mathrm{pH}$ measurement was determined by a $\mathrm{pH}$ meter (Fisher Scientific, Pittsburgh, PA).

Mycelia were collected by filtration and washed twice with distilled water. Cell mass was determined by drying under $105 \pm 1{ }^{\circ} \mathrm{C}$ to obtain a consistent weight. Glucose, xylose, acetic acid, formic acid, furfural, and hydroxymethylfurfural (HMF) in the co-hydrolysates and fermentation broths were determined by High Performance Liquid Chromatography (Shimadzu Prominence, Kyoto, Japan) equipped with a Biorad Aminex HPX-87H analytical column and a refractive index detector. The mobile phase was $0.005 \mathrm{~mol} \mathrm{~L}^{-1}$ sulfuric

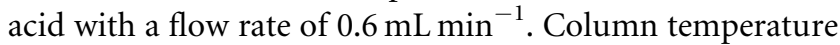
was set at $65^{\circ} \mathrm{C}$. HPLC standards including glucose (Catalog Number: 49158), xylose (Catalog Number: 95729), sodium acetate (Catalog Number: S8750), sodium formate (Catalog Number: 17841), HMF (Catalog Number: 53407), and furfural (Catalog Number: 185914) were purchased from Sigma-Aldrich. Dried mycelia were ground in a mortar and used for lipid extraction. Total lipid was determined gravimetrically (Ruan et al., 2012).

\section{Statistical Analysis}

A general linear model using $\mathrm{R}$ software ( $\mathrm{R}$ Version 2.15.0, Vienna, Austria) was applied to the experimental data in order to perform an analysis of variance (ANOVA) and multiple comparisons. Tukey's test, using a comparisonwise type I error rate of 0.05 , was adopted to compute honestly significant differences among different feedstocks regarding sugar yield and inhibitor generation. Within each feedstock, the significance of individual factors, as well as the interactions between factors on sugar conversion and inhibitors generation, was identified using ANOVA analysis. Bonferroni's test was carried out at an experimental type I error rate of 0.05 to conduct multiple comparisons of both 
Table I. Structural carbohydrate and lignin of four raw lignocellulosic biomass.*

\begin{tabular}{lccc}
\hline Biomass & $\begin{array}{c}\text { Cellulose } \\
(\mathrm{w} / \mathrm{w}, \%)\end{array}$ & $\begin{array}{c}\text { Xylan } \\
(\mathrm{w} / \mathrm{w}, \%)\end{array}$ & $\begin{array}{c}\text { Lignin } \\
(\mathrm{w} / \mathrm{w}, \%)\end{array}$ \\
\hline Corn stover & 36.3 & 22.0 & 18.6 \\
Switchgrass & 37.4 & 22.1 & 20.5 \\
Miscanthus & 34.2 & 19.0 & 22.9 \\
Giant reed & 29.7 & 19.2 & 22.1 \\
\hline
\end{tabular}

*The particle size of raw biomass was between 1 and $1.6 \mathrm{~mm}$; compositional data were the average of two replicates.

sugar and inhibitor production under different co-hydrolysis conditions.

\section{Results and Discussion}

\section{Degradation of Carbohydrate Into Sugars and Inhibitors}

The composition of lignocellulosic biomass indicated that cellulose was the most abundant fraction in each feedstock (Table I). Corn stover and switchgrass exhibited similar but higher cellulose content (36.3\% and $37.4 \%$, respectively) compared to miscanthus (34.2\%) and giant reed (29.7\%), respectively. The hemicellulose fraction in each feedstock was of a xylan type as indicated by the relatively high amounts of xylose in the polysaccharide. The xylan content for corn stover $(22.0 \%)$ and switchgrass $(22.1 \%)$ were equivalent; while miscanthus $(19.0 \%)$ and giant reed (19.2\%) had comparatively lower levels. In addition, miscanthus and giant reed contained more lignin $(22.9 \%$ and $22.1 \%$, respectively), compared to switchgrass (20.5\%), and corn stover $(18.6 \%)$.
Dilute acid pretreatment and enzymatic hydrolysis using both the conventional and co-hydrolysis processes were represented in Figure 1. Results from the co-hydrolysis process at various pretreatment conditions were listed in Tables II-V and summarized in Figure 2. ANOVA and Tukey's HSD analysis indicated that there were significant $(P<0.0001)$ mean differences on sugar yields between feedstocks, with the exception of miscanthus and giant reed $(P>0.05)$.

The sugar yield for corn stover co-hydrolysis was dependent on the main factors of pretreatment temperature and sulfuric acid concentration $(P<0.05)$, but independent of treatment time $(P>0.05)$. There were also significant two-way interactions between time and temperature $(P<0.05)$, time and sulfuric acid concentration $(P<0.05)$, and temperature and sulfuric acid concentration $(P<0.05)$. A pretreatment condition of $130^{\circ} \mathrm{C}, 2 \% \mathrm{H}_{2} \mathrm{SO}_{4}$ for $1 \mathrm{~h}$ led to the greatest sugar yield of $0.545 \mathrm{~g} \mathrm{~g}^{-1}$ dry initial biomass and $83.3 \%$ of theoretical combined glucose and xylose yield for corn stover, producing a total of $52.09 \pm 0.13 \mathrm{~g} \mathrm{~L}^{-1}$ of fermentable sugars, including $31.1 \pm 0.38 \mathrm{~g} \mathrm{~L}^{-1}$ glucose and $21.0 \pm 0.51 \mathrm{~g} \mathrm{~L}^{-1}$ xylose (Table II and Fig. 2A).

ANOVA analysis indicated that the sugar yield of switchgrass co-hydrolysis was independent of pretreatment temperature, time, and sulfuric acid concentration. The effects of two-factor interactions between time and sulfuric acid concentration $(P<0.05)$, as well as temperature and sulfuric acid concentration $(P<0.05)$ were significant. The treatments of $2 \% \mathrm{H}_{2} \mathrm{SO}_{4}$ at $130^{\circ} \mathrm{C}$ for $2 \mathrm{~h}$ had the highest sugar yield of $0.44 \mathrm{gg}^{-1}$ dry initial biomass and $65.8 \%$ of theoretical combined glucose and xylose yield (Table III). It generated $22.8 \pm 1.22 \mathrm{~g} \mathrm{~L}^{-1}$ glucose and $19.23 \pm 0.16 \mathrm{~g} \mathrm{~L}^{-1}$ xylose (Fig. 2B).

\section{Conventional process}

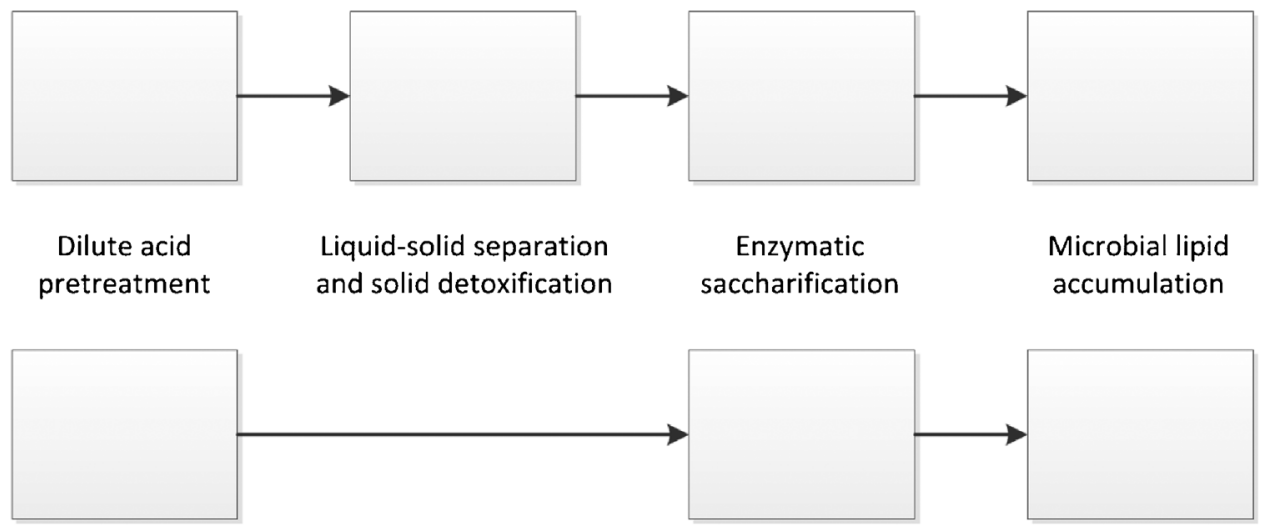

Co-hydrolysis

Figure 1. Conventional and co-hydrolysis process of dilute acid pretreatment and enzymatic saccharification operation for microbial lipid production (modified from Studer et al., 2011). 
Table II. Fermentable sugars yield and inhibitory compounds derived from co-hydrolysate of corn stover.

\begin{tabular}{|c|c|c|c|c|c|c|c|c|}
\hline \multicolumn{3}{|c|}{$\begin{array}{l}\text { Dilute acid pretreatment } \\
\text { parameters }\end{array}$} & \multicolumn{3}{|c|}{ Sugar yields } & \multicolumn{3}{|c|}{ Inhibitory compounds } \\
\hline $\begin{array}{l}\text { Acid } \\
(\mathrm{w} / \mathrm{w} \%)\end{array}$ & $\begin{array}{l}\text { Temp } \\
\left({ }^{\circ} \mathrm{C}\right)\end{array}$ & $\begin{array}{l}\text { Time } \\
(\mathrm{h})\end{array}$ & $\log C S$ & $\begin{array}{c}\text { Glu }+ \text { Xyl } \\
\left(\mathrm{g} \mathrm{g}^{-1}, \text { dry biomass }\right)\end{array}$ & $\begin{array}{c}\text { Glu }+ \text { Xyl } \\
(\% \text { of theoretical yield })\end{array}$ & $\begin{array}{l}\text { Acetate } \\
\left(\mathrm{g} \mathrm{L}^{-1}\right)\end{array}$ & $\begin{array}{c}\mathrm{HMF} \\
\left(\mathrm{mg} \mathrm{L}^{-1}\right)\end{array}$ & $\begin{array}{l}\text { Furfural } \\
\left(\mathrm{g} \mathrm{L}^{-1}\right)\end{array}$ \\
\hline 1 & 120 & 1 & 1.29 & 0.455 & 69.5 & 3.49 & 53.05 & 0.07 \\
\hline 2 & 120 & 1 & 1.65 & 0.503 & 76.8 & 3.83 & 77.57 & 0.17 \\
\hline 3 & 120 & 1 & 1.85 & 0.510 & 78.0 & 3.88 & 82.39 & 0.3 \\
\hline 1 & 120 & 2 & 1.57 & 0.475 & 72.6 & 3.53 & 65.14 & 0.14 \\
\hline 2 & 120 & 2 & 1.90 & 0.516 & 78.8 & 3.94 & 92.53 & 0.43 \\
\hline 3 & 120 & 2 & 2.10 & 0.505 & 77.1 & 4.01 & 72.36 & 0.64 \\
\hline 1 & 120 & 3 & 1.97 & 0.507 & 77.4 & 3.66 & 86.14 & 0.3 \\
\hline 2 & 120 & 3 & 2.22 & 0.527 & 80.5 & 4.21 & 96.76 & 0.8 \\
\hline 3 & 120 & 3 & 2.35 & 0.491 & 75.0 & 4.18 & 93.32 & 0.91 \\
\hline 1 & 130 & 1 & 1.62 & 0.513 & 78.4 & 3.64 & 89.98 & 0.25 \\
\hline 2 & 130 & 1 & 1.94 & 0.545 & 83.3 & 4.08 & 109.7 & 0.63 \\
\hline 3 & 130 & 1 & 2.18 & 0.513 & 78.5 & 4.02 & 98.69 & 0.59 \\
\hline 1 & 130 & 2 & 1.92 & 0.519 & 79.4 & 3.5 & 114.5 & 0.3 \\
\hline 2 & 130 & 2 & 2.18 & 0.512 & 78.3 & 3.97 & 110.8 & 0.7 \\
\hline 3 & 130 & 2 & 2.37 & 0.474 & 72.4 & 4.17 & 107.2 & 0.97 \\
\hline 1 & 130 & 3 & 2.04 & 0.512 & 78.2 & 3.78 & 99.73 & 0.33 \\
\hline 2 & 130 & 3 & 2.50 & 0.521 & 79.6 & 4.04 & 102.0 & 0.72 \\
\hline 3 & 130 & 3 & 1.98 & 0.507 & 77.5 & 4.43 & 95.29 & 0.99 \\
\hline Mean & - & - & - & $0.506 \pm 0.021$ & $77.3 \pm 3.2$ & $3.92 \pm 0.29$ & $91.8 \pm 17.8$ & $0.54 \pm 0.31$ \\
\hline
\end{tabular}

(1) NREL's analysis of structural carbohydrate and lignin: cellulose: $36.3 \%(w / w)$; xylan: $22.0 \%(w / w)$; lignin: $18.6 \%$ (w/w).

(2) Dilute acid pretreatment was carried out at $10 \%(\mathrm{w} / \mathrm{w})$ dry solids. Enzymatic saccharification was studied at $8 \%(\mathrm{w} / \mathrm{w})$ dry solids with (35 mg Accellerase 1500 and $2.15 \mathrm{mg}$ Accellerase XY) per gram dry biomass.

(3) All the sugar and inhibitor values are the average of two replicates.

The sugar yield for giant reed co-hydrolysis was shown to be dependent on the main effects of pretreatment temperature $(P<0.0001)$, sulfuric acid concentration $(P<0.05)$, and pretreatment time $(P<0.05)$. Two-way interactions of time and sulfuric acid concentration $(P<0.0025)$, temperature and time $(P<0.0001)$ were also significant. Two different pretreatment conditions $\left(3 \% \mathrm{H}_{2} \mathrm{SO}_{4}\right.$ at $130^{\circ} \mathrm{C}$ for $1 \mathrm{~h}$, and $2 \% \mathrm{H}_{2} \mathrm{SO}_{4}$ at $130^{\circ} \mathrm{C}$ for $1 \mathrm{~h}$ ) were both shown to have the highest sugar yield of $0.355 \mathrm{~g} \mathrm{~g}^{-1}$ dry initial biomass at $64.7 \%$ of the theoretical combined glucose and xylose yield (Table IV). However, the concentrations of individual sugars from these two pretreatment conditions were significantly different $(P<0.05)$. The treatment condition of $3 \% \mathrm{H}_{2} \mathrm{SO}_{4}, 130^{\circ} \mathrm{C}$, and $1 \mathrm{~h}$ generated $18.35 \pm 0.67 \mathrm{~g} \mathrm{~L}^{-1}$ glucose and $15.56 \pm 0.46 \mathrm{~g} \mathrm{~L}^{-1}$ xylose, while the treatment condition of $2 \% \mathrm{H}_{2} \mathrm{SO}_{4}$ at $130^{\circ} \mathrm{C}$ for $1 \mathrm{~h}$ released $16.71 \pm 0.76 \mathrm{~g} \mathrm{~L}^{-1}$ glucose and $17.2 \pm 0.14 \mathrm{~g} \mathrm{~L}^{-1}$ xylose, respectively (Fig. $2 \mathrm{C}$ ).

For the miscanthus co-hydrolysis combined ANOVA analysis showed that the main pretreatment factors of temperature $(P<0.0001)$, time $(P<0.0001)$, and sulfuric acid concentration $(P<0.05)$ had significant impacts on the sugar yield, while the effects of two-factor interaction terms: temperature and time $(P<0.0001)$, temperature and sulfuric acid concentration $(P<0.05)$, time and sulfuric acid concentration $(P<0.05)$ as well as the three-factor interaction of temperature, time, and sulfuric acid concentration $(P<0.05)$ were also considered statistically significant. The highest sugar yield was $0.349 \mathrm{gg}^{-1}$ dry initial biomass at $58.1 \%$ of the theoretical combined sugar yield from the treatment of $2 \% \mathrm{H}_{2} \mathrm{SO}_{4}$ at $130^{\circ} \mathrm{C}$ for $2 \mathrm{~h}$ (Table V), corresponding to $17.76 \pm 0.94 \mathrm{~g} \mathrm{~L}^{-1}$ glucose and $15.55 \pm 0.08 \mathrm{~g} \mathrm{~L}^{-1}$ xylose, respectively (Fig. $2 \mathrm{D}$ ).

Comparison of co-hydrolysis of the four feedstocks demonstrated that sugar yields of miscanthus and giant reed were significantly $(P<0.0001)$ lower than corn stover and switchgrass. The lower yields were possibly due to those feedstocks having relatively higher lignin contents which likely hindered the enzyme action due to steric actions or absorbing active enzymes during the enzymatic hydrolysis step in the co-hydrolysis process (Liao et al., 2005; Yang and Wyman, 2006).

The co-hydrolysis of corn stover generated the lowest mean concentration of acetic acid $\left(3.92 \pm 0.29 \mathrm{~g} \mathrm{~L}^{-1}\right.$; Table II), followed by switchgrass $\left(4.04 \pm 0.32 \mathrm{gL}^{-1}\right.$; Table III), miscanthus (5.12 $\pm 0.65 \mathrm{~g} \mathrm{~L}^{-1}$; Table V) and giant reed $\left(5.66 \pm 0.86 \mathrm{~g} \mathrm{~L}^{-1}\right.$; Table IV). Tukey's HSD analysis showed that corn stover and switchgrass had no significant $(P>0.05)$ differences for acetate generation at the comparison-wise type I error rate of 0.05 , while miscanthus and giant reed were significantly different from corn stover and switchgrass $(P<0.0001)$. Under the best co-hydrolysis conditions of sugar production, the acetic acid concentrations reached $6.43 \mathrm{~g} \mathrm{~L}^{-1}$ in miscanthus hydrolysate (Table V) and 6.79 or $6.31 \mathrm{~g} \mathrm{~L}^{-1}$ for giant reed (Table IV), respectively. In contrast, an acetate concentration of $4.08 \mathrm{~g} \mathrm{~L}^{-1}$ was obtained from co-hydrolysis of corn stover (Table II) and $4.2 \mathrm{gL}^{-1}$ from switchgrass, respectively (Table III). 


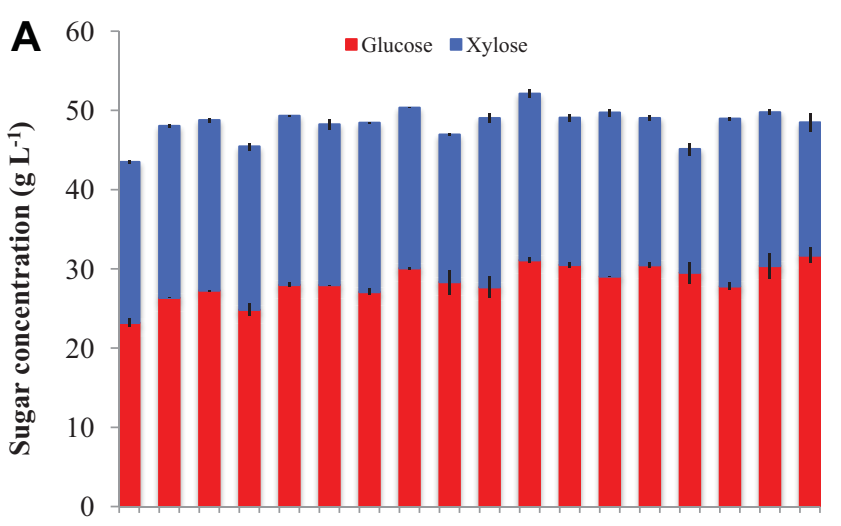

wै

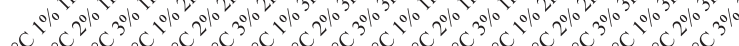

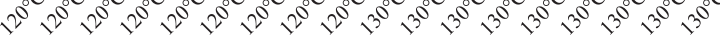

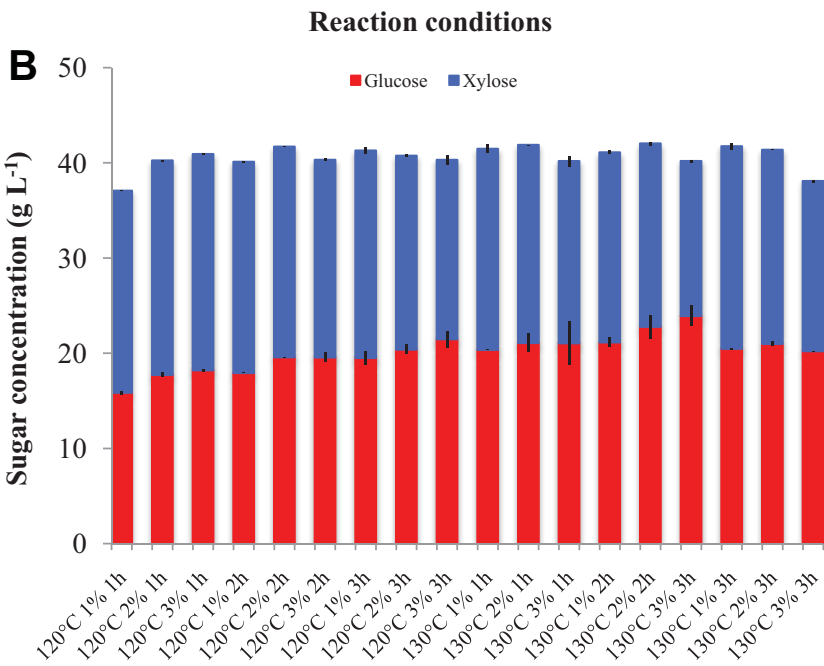

Reaction conditions

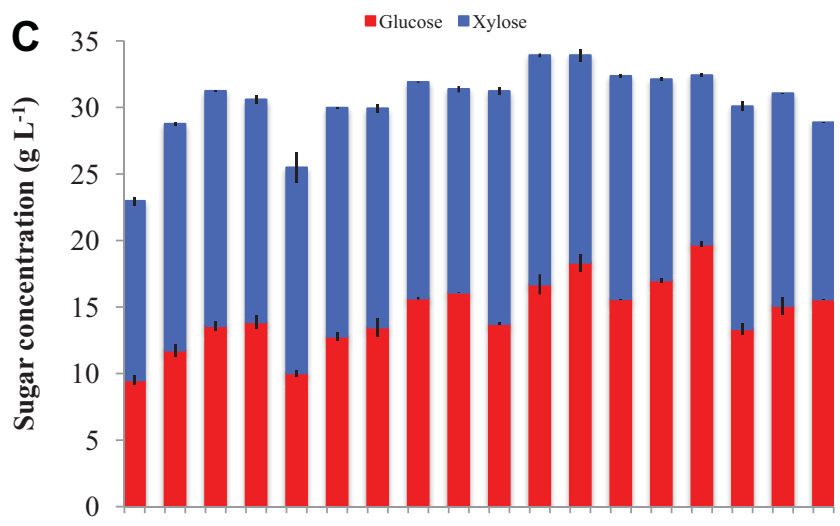

v

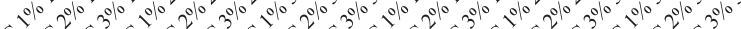

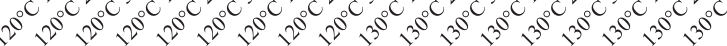

Reaction conditions

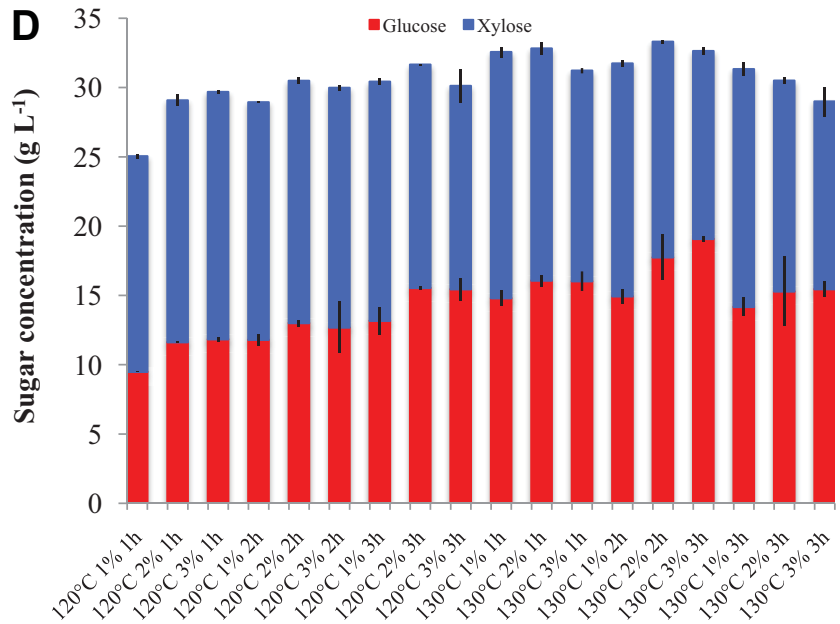

Reaction conditions

Figure 2. Glucose and xylose production from corn stover (A), switchgrass (B), giant reed (C), and miscanthus (D).

Furfural and HMF are generated by thermal conversion of pentoses and hexoses. The experimental results (Tables II-V) demonstrated that, among the four feedstocks, corn stover co-hydrolysate exhibited the lowest mean concentrations of furfural $\left(0.54 \pm 0.31 \mathrm{~g} \mathrm{~L}^{-1}\right)$ and HMF $\left(0.0918 \pm 0.018 \mathrm{~g} \mathrm{~L}^{-1}\right)$, switchgrass co-hydrolysate had the highest mean furfural concentration $\left(0.77 \pm 0.41 \mathrm{~g} \mathrm{~L}^{-1}\right)$, and giant reed co-hydrolysate had the highest mean HMF concentration $\left(0.24 \pm 0.12 \mathrm{~g} \mathrm{~L}^{-1}\right)$. Tukey's HSD analysis exhibited that there were significant differences in HMF concentrations between corn stover and giant reed $(P<0.0001)$, miscanthus and giant reed $(P<0.0001)$, as well as switchgrass and giant reed $(P<0.0001)$. However, miscanthus and corn stover $(P>0.05)$, switchgrass and corn stover $(P>0.05)$, switchgrass and miscanthus $(P>0.05)$ were not significantly different in regards to HMF concentrations. Tukey's HSD also indicated that there were no significant differences on furfural concentrations among the four feedstocks $(P>0.05)$.

\section{Combined Severity Factor Analysis}

The effects of combined severity factor on the co-hydrolysis of the four feedstocks were presented in Figure 3. The concentrations of glucose, xylose, acetate, HMF, and furfural were chosen as the responses in order to evaluate the effects of the combined severity factor. The general trend for glucose production in the feedstocks was an initial increase with greater combined severity factor followed by a decrease at higher severity factor levels. Corn stover was an exception to this trend showing no decrease in glucose production even at higher severity levels. It was clear that xylose release was negatively associated with the combined severity factor for all materials due to the degradation 
Table III. Fermentable sugars yield and inhibitory compounds derived from co-hydrolysate of switchgrass.

Dilute acid pretreatment parameters

Sugar yields

Inhibitory compounds

\begin{tabular}{|c|c|c|c|c|c|c|c|c|}
\hline $\begin{array}{l}\text { Acid } \\
(w / w, \%)\end{array}$ & $\begin{array}{l}\text { Temp. } \\
\left({ }^{\circ} \mathrm{C}\right)\end{array}$ & $\begin{array}{l}\text { Time } \\
\text { (h) }\end{array}$ & $\log C S$ & $\begin{array}{c}\text { Glu }+ \text { Xyl } \\
\left(\mathrm{gg}^{-1}, \text { dry biomass }\right)\end{array}$ & $\begin{array}{c}\text { Glu }+ \text { Xyl } \\
(\% \text { of theoretical yield })\end{array}$ & $\begin{array}{l}\text { Acetate } \\
\left(\mathrm{g} \mathrm{L}^{-1}\right)\end{array}$ & $\begin{array}{c}\mathrm{HMF} \\
\left(\mathrm{mg} \mathrm{L}^{-1}\right)\end{array}$ & $\begin{array}{l}\text { Furfural } \\
\left(\mathrm{g} \mathrm{L}^{-1}\right)\end{array}$ \\
\hline 1 & 120 & 1 & 1.33 & 0.388 & 57.9 & 3.47 & 98.54 & 0.22 \\
\hline 2 & 120 & 1 & 1.65 & 0.421 & 62.9 & 3.8 & 165.8 & 0.28 \\
\hline 3 & 120 & 1 & 1.84 & 0.428 & 64.0 & 4.02 & 164.1 & 0.39 \\
\hline 1 & 120 & 2 & 1.57 & 0.42 & 62.7 & 3.78 & 165.9 & 0.31 \\
\hline 2 & 120 & 2 & 1.93 & 0.436 & 65.2 & 3.81 & 170.6 & 0.43 \\
\hline 3 & 120 & 2 & 2.09 & 0.422 & 63.1 & 4.08 & 140.8 & 0.87 \\
\hline 1 & 120 & 3 & 1.89 & 0.432 & 64.6 & 3.91 & 183.2 & 0.52 \\
\hline 2 & 120 & 3 & 2.22 & 0.426 & 63.7 & 4.13 & 135.6 & 1.03 \\
\hline 3 & 120 & 3 & 2.32 & 0.422 & 63.1 & 4.5 & 100.8 & 1.32 \\
\hline 1 & 130 & 1 & 1.85 & 0.434 & 64.9 & 3.67 & 187.4 & 0.48 \\
\hline 2 & 130 & 1 & 2.04 & 0.438 & 65.5 & 4.05 & 168.6 & 0.88 \\
\hline 3 & 130 & 1 & 2.18 & 0.421 & 62.9 & 4.11 & 140.4 & 0.81 \\
\hline 1 & 130 & 2 & 2.00 & 0.433 & 64.7 & 3.79 & 191.4 & 0.57 \\
\hline 2 & 130 & 2 & 2.14 & 0.44 & 65.8 & 4.20 & 146.9 & 0.96 \\
\hline 3 & 130 & 2 & 2.37 & 0.415 & 62.1 & 4.4 & 136.3 & 1.17 \\
\hline 1 & 130 & 3 & 2.13 & 0.437 & 65.3 & 3.88 & 198.7 & 0.56 \\
\hline 2 & 130 & 3 & 2.50 & 0.433 & 64.7 & 4.41 & 155 & 1.29 \\
\hline 3 & 130 & 3 & 2.65 & 0.399 & 59.6 & 4.61 & 132.8 & 1.56 \\
\hline Mean & - & - & - & $0.425 \pm 0.015$ & $63.5 \pm 2.05$ & $4.04 \pm 0.32$ & $155.4 \pm 28.3$ & $0.77 \pm 0.41$ \\
\hline
\end{tabular}

(1) NREL's analysis of structural carbohydrate and lignin: cellulose: $37.4 \%(\mathrm{w} / \mathrm{w})$; xylan: $22.1 \%(\mathrm{w} / \mathrm{w})$; lignin: $20.5 \%$ (w/w).

(2) Dilute acid pretreatment was carried out at $10 \%(\mathrm{w} / \mathrm{w})$ dry solids. Enzymatic saccharification was studied at $8 \%$ (w/w) dry solids with (35 mg Accellerase 1500 and $2.15 \mathrm{mg}$ Accellerase XY) per gram dry biomass.

(3) All the sugar and inhibitor values are the average of two replicates.

Table IV. Fermentable sugars yield and inhibitory compounds derived from co-hydrolysate of giant reed.

\begin{tabular}{|c|c|c|c|c|c|c|c|c|}
\hline \multicolumn{3}{|c|}{$\begin{array}{l}\text { Dilute acid pretreatment } \\
\text { parameters }\end{array}$} & \multicolumn{3}{|c|}{ Sugar yield } & \multicolumn{3}{|c|}{ Inhibitory compounds } \\
\hline $\begin{array}{l}\text { Acid } \\
(\mathrm{w} / \mathrm{w}, \%)\end{array}$ & $\begin{array}{l}\text { Temp. } \\
\left({ }^{\circ} \mathrm{C}\right)\end{array}$ & $\begin{array}{c}\text { Time } \\
\text { (h) }\end{array}$ & $\log$ CS & $\begin{array}{c}\mathrm{Glu}+\mathrm{Xyl} \\
\left(\mathrm{gg}^{-1}, \text { dry biomass }\right)\end{array}$ & $\begin{array}{c}\text { Glu }+ \text { Xyl } \\
(\% \text { of theoretical yield })\end{array}$ & $\begin{array}{l}\text { Acetate } \\
\left(\mathrm{g} \mathrm{L}^{-1}\right)\end{array}$ & $\begin{array}{c}\mathrm{HMF} \\
\left(\mathrm{mg} \mathrm{L}^{-1}\right)\end{array}$ & $\begin{array}{l}\text { Furfural } \\
\left(\mathrm{g} \mathrm{L}^{-1}\right)\end{array}$ \\
\hline 1 & 120 & 1 & 1.22 & 0.240 & 43.8 & 3.87 & 270.6 & 0.04 \\
\hline 2 & 120 & 1 & 1.62 & 0.301 & 54.8 & 5.27 & 352.2 & 0.18 \\
\hline 3 & 120 & 1 & 1.84 & 0.327 & 59.6 & 5.84 & 307.6 & 0.31 \\
\hline 1 & 120 & 2 & 2.00 & 0.32 & 58.3 & 6.34 & 199.5 & 0.75 \\
\hline 2 & 120 & 2 & 1.50 & 0.267 & 48.6 & 4.52 & 351.1 & 0.15 \\
\hline 3 & 120 & 2 & 1.77 & 0.314 & 57.2 & 5.45 & 331.4 & 0.3 \\
\hline 1 & 120 & 3 & 1.84 & 0.313 & 57.1 & 5.46 & 347.2 & 0.4 \\
\hline 2 & 120 & 3 & 2.10 & 0.334 & 60.8 & 6.27 & 209.9 & 0.65 \\
\hline 3 & 120 & 3 & 2.37 & 0.328 & 59.8 & 6.74 & 111.1 & 1.02 \\
\hline 1 & 130 & 1 & 1.66 & 0.327 & 59.5 & 5.5 & 424.3 & 0.44 \\
\hline 2 & 130 & 1 & 1.98 & 0.355 & 64.7 & 6.31 & 263.1 & 0.71 \\
\hline 3 & 130 & 1 & 2.18 & 0.355 & 64.7 & 6.79 & 123.5 & 0.83 \\
\hline 1 & 130 & 2 & 2.16 & 0.339 & 61.7 & 4.61 & 124.2 & 0.5 \\
\hline 2 & 130 & 2 & 2.33 & 0.336 & 61.2 & 4.97 & 78.0 & 0.92 \\
\hline 3 & 130 & 2 & 2.52 & 0.339 & 61.8 & 5.19 & 74.65 & 0.81 \\
\hline 1 & 130 & 3 & 2.04 & 0.315 & 57.4 & 5.47 & 420.6 & 0.56 \\
\hline 2 & 130 & 3 & 2.39 & 0.325 & 59.2 & 6.25 & 200 & 1.0 \\
\hline 3 & 130 & 3 & 2.61 & 0.302 & 55.0 & 6.98 & 105 & 1.01 \\
\hline Mean & - & - & - & $0.319 \pm 0.028$ & $58.1 \pm 5.18$ & $5.66 \pm 0.86$ & $238.6 \pm 117.2$ & $0.59 \pm 0.33$ \\
\hline
\end{tabular}

(1) NREL's analysis of structural carbohydrate and lignin: cellulose: $34.2 \%(\mathrm{w} / \mathrm{w})$; xylan: $19.0 \%(\mathrm{w} / \mathrm{w})$; lignin: $22.9 \%(\mathrm{w} / \mathrm{w})$.

(2) Dilute acid pretreatment was carried out at $10 \%(\mathrm{w} / \mathrm{w})$ dry solids. Enzymatic saccharification was studied at $8 \%(\mathrm{w} / \mathrm{w})$ dry solids with (35 mg Accellerase 1500 and $2.15 \mathrm{mg}$ Accellerase XY) per gram dry biomass.

(3) All the sugar and inhibitor values are the average of two replicates. 
Table V. Fermentable sugars yield and inhibitory compounds derived from co-hydrolysate of miscanthus.

\begin{tabular}{|c|c|c|c|c|c|c|c|c|}
\hline \multicolumn{3}{|c|}{$\begin{array}{l}\text { Dilute acid pretreatment } \\
\text { parameters }\end{array}$} & \multicolumn{3}{|c|}{ Sugar yields } & \multicolumn{3}{|c|}{ Inhibitory compounds } \\
\hline $\begin{array}{l}\text { Acid } \\
(\mathrm{w} / \mathrm{w}, \%)\end{array}$ & $\begin{array}{l}\text { Temp } \\
\left({ }^{\circ} \mathrm{C}\right)\end{array}$ & $\begin{array}{c}\text { Time } \\
\text { (h) }\end{array}$ & $\log C S$ & $\begin{array}{c}\text { Glu }+ \text { Xyl } \\
\left(\mathrm{g} \mathrm{g}^{-1}, \text { dry biomass }\right)\end{array}$ & $\begin{array}{c}\text { Glu }+ \text { Xyl } \\
(\% \text { of theoretical yield })\end{array}$ & $\begin{array}{l}\text { Acetate } \\
\left(\mathrm{g} \mathrm{L}^{-1}\right)\end{array}$ & $\begin{array}{c}\mathrm{HMF} \\
\left(\mathrm{mg} \mathrm{L}^{-1}\right)\end{array}$ & $\begin{array}{l}\text { Furfural } \\
\left(\mathrm{g} \mathrm{L}^{-1}\right)\end{array}$ \\
\hline 1 & 120 & 1 & 1.36 & 0.262 & 43.8 & 4.22 & 102.8 & 0.06 \\
\hline 2 & 120 & 1 & 1.67 & 0.305 & 50.9 & 4.79 & 125.8 & 0.17 \\
\hline 3 & 120 & 1 & 1.87 & 0.311 & 51.9 & 4.96 & 116.8 & 0.26 \\
\hline 1 & 120 & 2 & 1.58 & 0.303 & 50.6 & 4.55 & 134.6 & 0.18 \\
\hline 2 & 120 & 2 & 1.89 & 0.319 & 53.3 & 4.86 & 121 & 0.37 \\
\hline 3 & 120 & 2 & 2.08 & 0.314 & 52.4 & 5.0 & 86.8 & 0.62 \\
\hline 1 & 120 & 3 & 1.95 & 0.319 & 53.2 & 4.69 & 109.2 & 0.32 \\
\hline 2 & 120 & 3 & 2.23 & 0.332 & 55.3 & 4.98 & 73.8 & 0.76 \\
\hline 3 & 120 & 3 & 2.42 & 0.315 & 52.6 & 5.21 & 66.47 & 1.06 \\
\hline 1 & 130 & 1 & 1.74 & 0.341 & 56.9 & 4.81 & 155.6 & 0.37 \\
\hline 2 & 130 & 1 & 1.99 & 0.344 & 57.3 & 5.21 & 85.13 & 0.96 \\
\hline 3 & 130 & 1 & 2.17 & 0.327 & 54.5 & 5.02 & 68.68 & 0.91 \\
\hline 1 & 130 & 2 & 1.94 & 0.332 & 55.5 & 5.12 & 201.8 & 0.37 \\
\hline 2 & 130 & 2 & 2.25 & 0.349 & 58.1 & 6.43 & 174.2 & 0.89 \\
\hline 3 & 130 & 2 & 2.46 & 0.342 & 56.9 & 6.93 & 114.7 & 0.88 \\
\hline 1 & 130 & 3 & 2.24 & 0.328 & 54.8 & 4.67 & 126.3 & 0.41 \\
\hline 2 & 130 & 3 & 2.47 & 0.319 & 53.3 & 5.14 & 74.69 & 1.11 \\
\hline 3 & 130 & 3 & 2.63 & 0.304 & 50.6 & 5.52 & 72.83 & 1.49 \\
\hline Mean & - & - & - & $0.32 \pm 0.02$ & $53.4 \pm 3.35$ & $5.12 \pm 0.56$ & $111.7 \pm 37.7$ & $0.62 \pm 0.40$ \\
\hline
\end{tabular}

(1) NREL's analysis of structural carbohydrate and lignin: cellulose: $29.7 \%(\mathrm{w} / \mathrm{w})$; xylan: $19.2 \%(\mathrm{w} / \mathrm{w})$; lignin: $22.1 \%(\mathrm{w} / \mathrm{w})$.

(2) Dilute acid pretreatment was carried out at $10 \%(w / w)$ dry solids. Enzymatic saccharification was studied at $8 \%(w / w)$ dry solids with (35 mg Accellerase 1500 and $2.15 \mathrm{mg}$ Accellerase XY) per gram dry biomass.

(3) All the sugar and inhibitor values are the average of two replicates.

of xylose into byproducts, mainly furfural, under harsh conditions. This corresponded well to the fact that furfural generation was positively correlated with the combined severity factor in all samples. Acetic acid likewise showed a positive correlation with combined severity factor, particularly for miscanthus and giant reed. However, HMF production appeared to be independent of the combined severity factors for the range being studied.

The maximum overall sugar concentrations for corn stover, switchgrass, giant reed, and miscanthus were obtained in the combined severity factor ranges of 1.94, 2.14, 1.98, or 2.18, and 2.25, respectively (Tables II-V). This indicated that the three herbaceous perennial energy crops required harsher pretreatment conditions compared to corn stover. The combined severity analysis effectively allowed for the observation of sugar and inhibitor trends for co-hydrolysis with regards to the dilute acid pretreatment parameters.

\section{Microbial Lipid Accumulation From Lignocellulosic Hydrolysates}

The co-hydrolysates of corn stover, switchgrass, miscanthus, and giant reed obtained from the most effective hydrolysis conditions were evaluated for their potential uses as carbon sources to cultivate $M$. isabellina for lipid accumulation. The cell mass, lipid, and lipid productivity of $M$. isabellina cultivation, along with sugar concentrations and carbon/ nitrogen molar ratios in the culture medium were shown in Table VI.
The deleterious effects of acetic acid, furfural, and HMF on cell growth and lipid accumulation of yeasts has been studied (Chen et al., 2009; Hu et al., 2009; Huang et al., 2009, 2011), however, information regarding their effects on oleaginous fungal lipid accumulation is quite limited. The experimental results from this study demonstrated that M. isabellina cultured on different co-hydrolysates, with the exception of giant reed co-hydrolysate, exhibited comparable lipid accumulation compared to synthetic hydrolysate (Table VI). The switchgrass co-hydrolysates accumulated $4.4 \pm 0.44 \mathrm{~g} \mathrm{~L}^{-1}$ lipid at a culture time of $118 \mathrm{~h}$ with initial acetic acid, HMF, and furfural concentrations at $3.25 \pm 0.088,0.07 \pm 0.002$, and $0.97 \pm 0.02 \mathrm{~g} \mathrm{~L}^{-1}$, respectively, in the fermentation broth. Miscanthus co-hydrolysate produced $3.71 \pm 0.45 \mathrm{~g} \mathrm{~L}^{-1}$ lipid at the same culture time with initial concentrations of acetic acid, HMF, and furfural in the fermentation broth of $5.01 \pm 0.039,0.07 \pm 0.0009$, and $0.92 \pm 0.02 \mathrm{~g} \mathrm{~L}^{-1}$, respectively. The corn stover cohydrolysate produced $3.18 \pm 0.02 \mathrm{~g} \mathrm{~L}^{-1}$ lipid at $88 \mathrm{~h}$ with initial acetic acid, HMF, and furfural concentrations of $2.4 \pm 0.004,0.02 \pm 0.0004$, and $0.19 \pm 0.0097 \mathrm{~g} \mathrm{~L}^{-1}$, respectively, in the culture broth. The synthetic hydrolysate produced $3.15 \pm 1.13 \mathrm{~g} \mathrm{~L}^{-1}$ lipid at $68 \mathrm{~h}$. While giant reed co-hydrolysate generated $3.02 \pm 0.31 \mathrm{~g} \mathrm{~L}^{-1}$ lipid at $136 \mathrm{~h}$ accompanied by initial acetic acid, HMF and furfural concentrations of $6.2 \pm 0.0735,0.19 \pm 0.0004$, and $0.51 \pm$ $0.019 \mathrm{~g} \mathrm{~L}^{-1}$ in culture media, respectively. Compared to the culture on synthetic hydrolysate, the increased cell mass from co-hydrolysates could be attributed to the strain's 

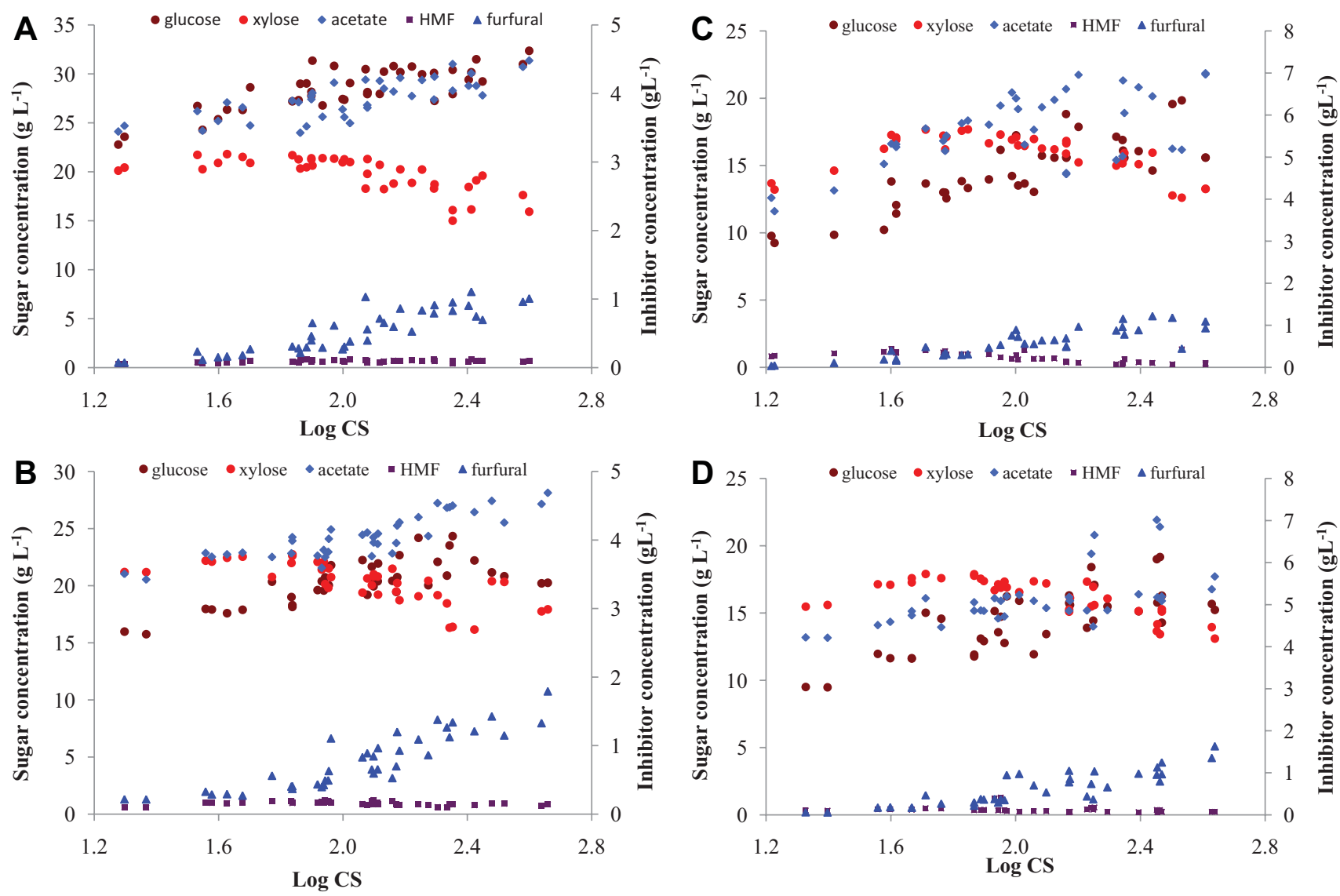

Figure 3. Effect of combined severity factor on the conversion of overall glucose and xylose, acetic acid, HMF, and furfural from corn stover (A), switchgrass (B), giant reed (C), and miscanthus (D).

capability of utilizing acetic acid and minor sugars such as galactose and arabinose (Chen et al., 2009; Cheng et al., 2008; Fei et al., 2011; Ruan et al., 2012) in co-hydrolysates. Experimental data also indicated that there was a correlation between the period of lag phase and inhibitor concentrations which lead to the difference of lipid productivity among various co-hydrolysates. It was found that the higher acetic acid, HMF and furfural concentrations in the fermentation broth, such as giant reed, the longer the lag phase and vice versa.

\section{Material Balances}

Mass balance analysis demonstrated the effects of cohydrolysates on utilization efficiency of different lignocellulosic biomass for microbial lipid production (Fig. 4). One

Table VI. Cell mass and microbial lipid accumulation of M. isabellina using corn stover, switchgrass, miscanthus, and giant reed co-hydrolysates.

\begin{tabular}{|c|c|c|c|c|c|c|c|}
\hline Carbon source & $\begin{array}{c}\mathrm{CN}^{-1 *} \\
\left(\mathrm{~mol} \mathrm{~mol}^{-1}\right)\end{array}$ & $\begin{array}{l}\text { Glucose } \\
\left(\mathrm{g} \mathrm{L}^{-1}\right)\end{array}$ & $\begin{array}{l}\text { Xylose } \\
\left(\mathrm{g} \mathrm{L}^{-1}\right)\end{array}$ & $\begin{array}{l}\text { Cell mass } \\
\left(X, \mathrm{~g} \mathrm{~L}^{-1}\right)\end{array}$ & $\begin{array}{c}\text { Lipid } \\
\left(L, \mathrm{gL}^{-1}\right)\end{array}$ & $\begin{array}{l}\% \text { Yield }_{L / X} \\
\quad\left(\mathrm{gg}^{-1}\right)\end{array}$ & $\begin{array}{l}\text { Lipid productivity } \\
\quad\left(\mathrm{g} \mathrm{L}^{-1} \mathrm{day}^{-1}\right)\end{array}$ \\
\hline Synthetic hydrolysate & $70.3 \pm 4.8$ & $13.66 \pm 0.37$ & $14.42 \pm 0.78$ & $10.4 \pm 0.23$ & $3.15 \pm 1.13$ & $30.66 \pm 11.77$ & $1.11 \pm 0.4$ \\
\hline Corn stover hydrolysate & $68.9 \pm 2.2$ & $15.0 \pm 0.04$ & $12.6 \pm 0.04$ & $12.84 \pm 0.23$ & $3.18 \pm 0.02$ & $24.82 \pm 0.75$ & $0.87 \pm 0.01$ \\
\hline Swichgrass hydrolysate & $71.5 \pm 0.3$ & $13.3 \pm 0.1$ & $15.3 \pm 0.5$ & $12.55 \pm 0.37$ & $4.4 \pm 0.44$ & $35.62 \pm 3.3$ & $0.90 \pm 0.09$ \\
\hline Miscanthus hydrolysate & $71 \pm 0.3$ & $13.2 \pm 0.1$ & $15.2 \pm 0.1$ & $12.28 \pm 0.02$ & $3.71 \pm 0.45$ & $32.21 \pm 3.18$ & $0.76 \pm 0.09$ \\
\hline Giant reed hydrolysate & $68.4 \pm 2.6$ & $12.1 \pm 0.1$ & $15.1 \pm 0.1$ & $13.75 \pm 0.87$ & $3.02 \pm 0.31$ & $21.18 \pm 0.96$ & $0.53 \pm 0.05$ \\
\hline
\end{tabular}

(1) Dilute acid pretreatment was carried out at $10 \%(\mathrm{w} / \mathrm{w})$ dry solids, pretreatment of corn stover was under $2 \%(\mathrm{w} / \mathrm{w})$ sulfuric acid, $1 \mathrm{~h}, 130^{\circ} \mathrm{C}$; switchgrass pretreatment was carried out at $2 \%(\mathrm{w} / \mathrm{w})$ sulfuric acid, $2 \mathrm{~h}, 130^{\circ} \mathrm{C}$; giant reed was treated under $3 \%(\mathrm{w} / \mathrm{w})$ sulfuric acid, $1 \mathrm{~h}, 130^{\circ} \mathrm{C}$; and miscanthus was pretreated using $2 \%(\mathrm{w} / \mathrm{w})$ sulfuric acid, $2 \mathrm{~h}, 130^{\circ} \mathrm{C}$.

(2) Enzymatic saccharification was studied at $8 \%(w / w)$ dry solids with (35 mg Accellerase 1500 and $2.15 \mathrm{mg}$ Accellerase XY) per gram dry mass.

(3) All the values are the average of three replicates plus standard deviation.

*For C:N molar ratio in the medium, it was assumed that yeast extract contained $12 \%(\mathrm{w} / \mathrm{w})$ of carbon source and $7 \%(\mathrm{w} / \mathrm{w})$ of nitrogen source. 


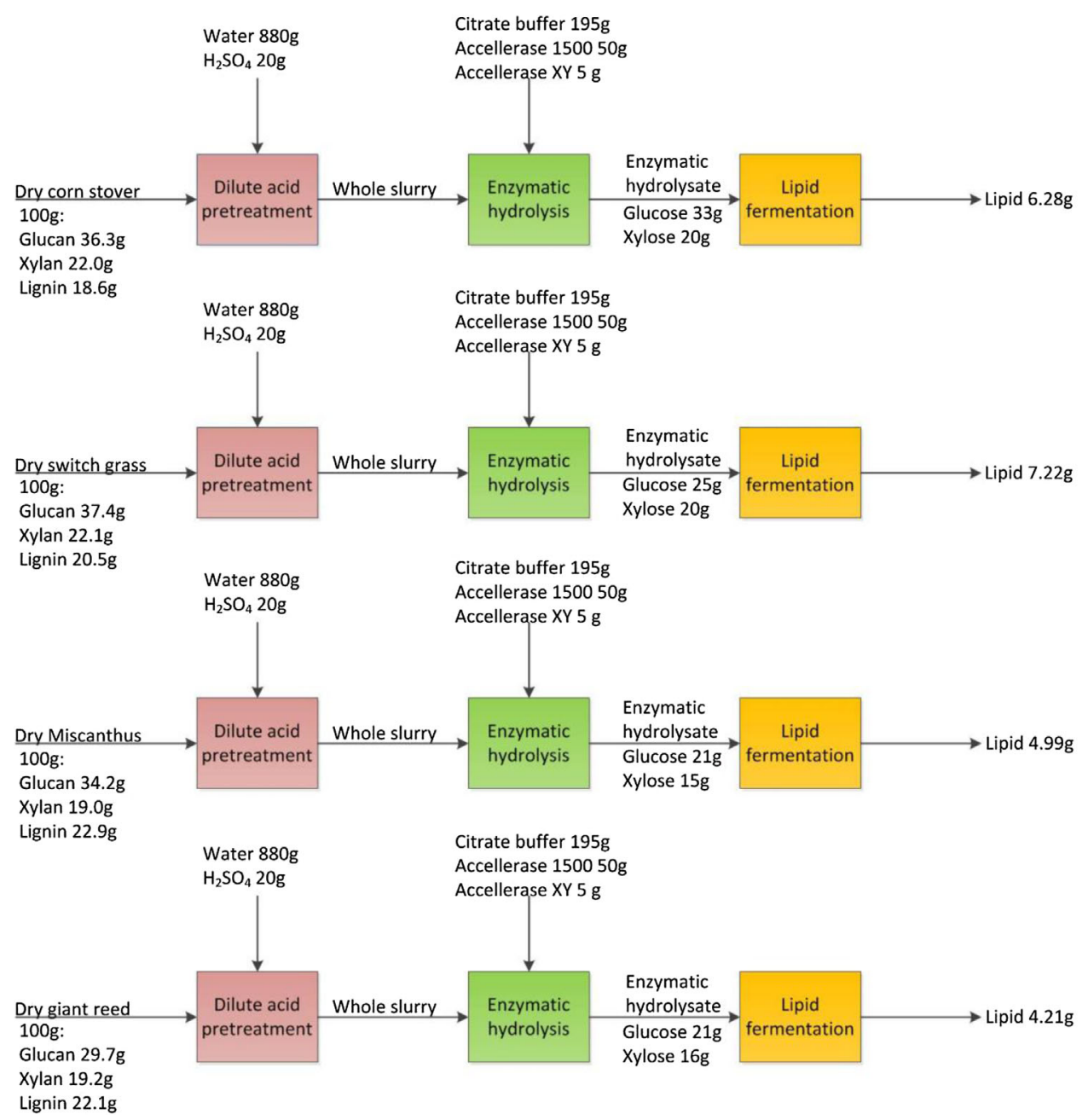

Figure 4. Flow chart indicating mass balance of microbial lipid accumulation from corn stover, switchgrass, miscanthus, and giant reed co-hydrolysates.

kilogram of dry corn stover contains $0.363 \mathrm{~kg}$ cellulose, $0.22 \mathrm{~kg}$ xylan, and $0.186 \mathrm{~kg}$ lignin. After co-hydrolysis, $0.33 \mathrm{~kg}$ of glucose and $0.20 \mathrm{~kg}$ of xylose were obtained resulting in the production of $0.0628 \mathrm{~kg}$ lipid from fungal fermentation ( $0.0628 \mathrm{~g} \mathrm{lipid} \mathrm{g}^{-1}$ corn stover). One kilogram of dry switchgrass contains $0.374 \mathrm{~kg}$ cellulose, $0.221 \mathrm{~kg}$ xylan, and $0.205 \mathrm{~kg}$ lignin. Cellulose and xylan were converted to $0.25 \mathrm{~kg}$ glucose and $0.20 \mathrm{~kg}$ xylose enabling $M$. isabellina to accumulate $0.0722 \mathrm{~kg}$ lipid $\left(0.0722 \mathrm{~g} \mathrm{lipid}^{-1}\right.$ switchgrass). One kilogram of dry miscanthus and giant reed were able to produce 0.0499 and $0.0421 \mathrm{~kg}$ lipid, respectively (0.0499 and $0.04211 \mathrm{~g} \mathrm{lipid} \mathrm{g}^{-1}$ biomass).

The mass balance analysis demonstrated that the M. isabellina lipid accumulation on co-hydrolysates were much superior to other widely studied lipid producing strains such as yeasts grown on similar feedstocks. It has been reported that the oleaginous yeast Trichosporon fermentans grown on un-detoxified sulfuric acid pretreated rice straw hydrolysate containing glucose $\left(5.1 \mathrm{~g} \mathrm{~L}^{-1}\right)$, xylose $\left(25.5 \mathrm{~g} \mathrm{~L}^{-1}\right)$, arabinose $\left(4.6 \mathrm{~g} \mathrm{~L}^{-1}\right)$, acetic acid $\left(1.4 \mathrm{~g} \mathrm{~L}^{-1}\right)$, furfural $\left(0.5 \mathrm{~g} \mathrm{~L}^{-1}\right)$, and $\operatorname{HMF}\left(0.08 \mathrm{~g} \mathrm{~L}^{-1}\right)$ resulted in a lipid yield of $0.017 \mathrm{glipid}^{-1}$ dry biomass (Huang et al., 2009). The comparison of lipid yield elucidated that oleaginous filamentous fungi could be a better microbial option to accumulate lipid from lignocellulosic biomass.

\section{Conclusion}

This study indicated that the co-hydrolysis process was a technically feasible method to maximize biomass conversion (generate C5/C6 sugars and acetic acid), and eliminate the need of a large amount of water for washing and detoxification. The oleaginous fungus M. isabellina ATCC 42613 further demonstrated its unique capacity to not only utilize glucose, xylose and acetic acid in the co-hydrolysates to accumulate fungal lipids, but also tolerate relatively high concentrations of inhibition products. These results 
conclude that combining co-hydrolysis of lignocellulosic feedstocks and M. isabellina cultivation for lipid accumulation could be a promising solution for advanced lignocellulosic fuel production.

\section{References}

Anderson WF, Dien BS, Brandon SK, Peterson JD. 2008. Assessment of bermudagrass and bunch grasses as feedstock for conversion to ethanol. Appl Biochem Biotechnol 145(1-3):13-21.

Brosse N, El Hage R, Sannigrahi P, Ragauskas A. 2010. Dilute sulphuric acid and ehanol organosolv pretreatment of Miscanthus xgiganteus. Cellulose Chem Technol 44(1-3):71-78.

Chen X, Li ZH, Zhang XX, Hu FX, Ryu DDY, Bao J. 2009. Screening of oleaginous yeast strains tolerant to lignocellulose degradation compounds. Appl Biochem Biotechnol 159(3):591-604.

Cheng KK, Cai BY, Zhang JA, Ling HZ, Zhou YH, Ge JP, Xu JM. 2008. Sugarcane bagasse hemicellulose hydrolysate for ethanol production by acid recovery process. Biochem Eng J 38(1):105-109.

Coyle WT. 2010. Next-generation biofuels: Near-term challenges and implications for agriculture. BIO-01-01 Economical Research Service USDA. May 2010.

de Vrije T, de Haas GG, Tan GB, Keijsers ERP, Claassen PAM. 2002. Pretreatment of miscanthus for hydrogen production by Thermotoga elfii. Int J Hydrogen Energy 27(11-12):1381-1390.

Decker SR, Brunecky R, Tucker MP, Himmel ME, Selig MJ. 2009. Highthroughput screening techniques for biomass conversion. Bioenergy Res 2(4):179-192.

Dien BS, Jung HJG, Vogel KP, Casler MD, Lamb JFS, Iten L, Mitchell RB, Sarath G. 2006. Chemical composition and response to dilute-acid pretreatment and enzymatic saccharification of alfalfa, reed canarygrass, and switchgrass. Biomass Bioenergy 30(10):880-891.

Economou ChN, Aggelis G, Pavlou S, Vayenas DV. 2011. Single cell oil production from rice hulls hydrolysate. Bioresour Technol 102(20): 9737-9742.

Fei Q, Chang HN, Shang LA, Choi JDR, Kim N, Kang J. 2011. The effect of volatile fatty acids as a sole carbon source on lipid accumulation by Cryptococcus albidus for biodiesel production. Bioresour Technol 102(3):2695-2701.

Felby C, Klinke HB, Olsen HS, Thomsen AB. 2003. Ethanol from wheat straw cellulose by wet oxidation pretreatment and simultaneous saccharification and fermentation. Appl Enzymes Lignocellulosics 855: $157-174$.

Georgieva TI, Hou XR, Hilstrom T, Ahring BK. 2008. Enzymatic hydrolysis and ethanol fermentation of high dry matter wet-exploded wheat straw at low enzyme loading. Appl Biochem Biotechnol 148(1-3): $35-44$.

Hu CM, Zhao X, Zhao J, Wu SG, Zhao ZBK. 2009. Effects of biomass hydrolysis by-products on oleaginous yeast Rhodosporidium toruloides. Bioresour Technol 100(20):4843-4847.

Huang C, Zong MH, Wu H, Liu QP. 2009. Microbial oil production from rice straw hydrolysate by Trichosporon fermentans. Bioresour Technol 100(19):4535-4538.
Huang C, Wu H, Liu QP, Li YY, Zong MH. 2011. Effects of aldehydes on the growth and lipid accumulation of oleaginous yeast Trichosporon fermentans. J Agric Food Chem 59(9):4606-4613.

Jorgensen H, Vibe-Pedersen J, Larsen J, Felby C. 2007. Liquefaction of lignocellulose at high-solids concentrations. Biotechnol Bioeng 96(5): 862-870.

Lewandowski I, Scurlock JMO, Lindvall E, Christou M. 2003. The development and current status of perennial rhizomatous grasses as energy crops in the US and Europe. Biomass Bioenergy 25(4): 335-361.

Liao W, Wen Z, Hurley S, Liu Y, Liu C, Chen S. 2005. Effects of hemicellulose and lignin on enzymatic hydrolysis of cellulose from dairy manure. Appl Biochem Biotechnol A Enzyme Eng Biotechnol 124(1-3):1017-1030.

Lloyd TA, Wyman CE. 2005. Combined sugar yields for dilute sulfuric acid pretreatment of corn stover followed by enzymatic hydrolysis of the remaining solids. Bioresour Technol 96(18):1967-1977.

Murnen HK, Balan V, Chundawat SPS, Bals B, Sousa LD, Dale BE. 2007. Optimization of ammonia fiber expansion (AFEX) pretreatment and enzymatic hydrolysis of Miscanthus xgiganteus to fermentable sugars. Biotechnol Prog 23(4):846-850.

Ruan Z, Zanotti M, Wang X, Ducey C, Liu Y. 2012. Evaluation of lipid accumulation from lignocellulosic sugars by Mortierella isabellina for biodiesel production. Bioresour Technol 110:198-205.

Scordia D, Cosentino SL, Lee JW, Jeffries TW. 2011. Dilute oxalic acid pretreatment for biorefining giant reed (Arundo donax L.). Biomass Bioenergy 35(7):3018-3024.

Scordia D, Cosentino SL, Lee J, Jeffries TW. 2012. Bioconversion of giant reed (Arundo donax L.) hemicellulose hydrolysate to ethanol by Scheffersomyces stipitis CBS6054. Biomass Bioenergy 39:10.

Shatalov AA, Pereira H. 2005. Kinetics of polysaccharide degradation during ethanol-alkali delignification of giant reed-Part 2. Minor carbohydrates and uronic acids. Carbohydr Polym 61(3):304-313.

Shatalov AA, Pereira H. 2012. Xylose production from giant reed (Arundo donax L.): Modeling and optimization of dilute acid hydrolysis. Carbohydr Polym 87(1):210-217.

Sluiter A. 2008. Determination of structural carbohydrates and lignin in biomass. Golden, CO, USA: National Renewable Energy Laboratory.

Sorensen A, Teller PJ, Hilstrom T, Ahring BK. 2008. Hydrolysis of miscanthus for bioethanol production using dilute acid presoaking combined with wet explosion pre-treatment and enzymatic treatment. Bioresour Technol 99(14):6602-6607.

Studer MH, Brethauer S, DeMartini JD, McKenzie HL, Wyman CE. 2011. Co-hydrolysis of hydrothermal and dilute acid pretreated populus slurries to support development of a high-throughput pretreatment system. Biotechnol for Biofuels 4:19.

Williams PR, Inman D, Aden A, Heath GA. 2009. Environmental and sustainability factors associated with next-generation biofuels in the U.S. What do we really know? Environ Sci Technol 43(13): 4763-4775.

Xing DH, Wang HL, Pan AL, Wang J, Xue DH. 2012. Assimilation of corn fiber hydrolysates and lipid accumulation by Mortierella isabellina. Biomass Bioenergy 39:494-501.

Yang B, Wyman CE. 2006. BSA treatment to enhance enzymatic hydrolysis of cellulose in lignin containing substrates. Biotechnol Bioeng 94(4): 611-617. 